\title{
Gambaran Perilaku Mencuci Tangan pada Penderita Diare di Desa Kintamani Kabupaten Bangli Bali Tahun 2015
}

\author{
Steven Awyono \\ Program Studi Pendidikan Dokter, Fakultas Kedokteran Universitas Udayana \\ nanaphen@yahoo.co.id
}

Diterima: 11 Juni 2016. Disetujui: 20 Juni 2016. Diterbitkan: Agustus 2016

\begin{abstract}
ABSTRAK
Diare masih merupakan penyebab kematian utama pada bayi dan balita. Dilihat dari kelompok umur, diare tersebar di semua kelompok umur dengan prevalensi tertinggi terdeteksi pada anak balita (1-4 tahun) yaitu 16,7\%. Berdasarkan data puskesmas Kintamani I pada tahun 2014 dilaporkan mengalami peningkatan sebesar 216 kasus dibandingkan dengan kunjungan tahun 2013. Desa kintamani memiliki angka kejadian diare tertinggi. Prevalensi diare di desa Kintamani meningkat dari 10,5\% (2013) menjadi 14,5\% (2014). Tujuan penelitian ini adalah untuk mengetahui gambaran perilaku mencuci tangan penderita diare dan non diare desa Kintamani tahun 2015, Kecamatan Kintamani, Kabupaten Bangli. Metode yang digunakan dalam melakukan penelitian adalah rancangan penelitian cross-sectional. Populasi penelitian ini adalah semua orang tua yang memiliki balita di Desa Kintamani. Pemilihan sampel dilakukan dengan teknik multi-stage sampling, dimana sampel merupakan 54 orang tua balita yang tinggal di Desa Kintamani. Analisis penelitian dilakukan secara deskriptif. Hasil dari penelitian menunjukkan perilaku mencuci tangan yang baik memiliki kejadian diare paling sedikit $(14,89 \%)$, diikuti oleh perilaku mencuci tangan kurang baik $(53,8 \%)$, dan paling banyak mengalami kejadian diare adalah perilaku mencuci tangan yang buruk (64,3\%).
\end{abstract}

Kata Kunci: Karakteristik Umum Responden, Perilaku Mencuci Tangan, Diare, Balita

\section{HAND WASHING HABIT IN DIARRHEA PATIENTS AT KINTAMANI VILLAGE BANGLI REGENCY BALI 2015}

\section{ABSTRACT}

Diarrhea is still the leading cause of death in infants and toddlers. Judging from the age group, diarrhea spread across all age groups with the highest prevalence detected in toddlers (1-4 years) is $16.7 \%$. Based on data from the first Kintamani health centers in 2014 reported an increase of 216 cases compared with visits in 2013. Village of Kintamani has the highest incidence of diarrhea. The prevalence of diarrhea in the village of Kintamani increased from $10.5 \%$ (2013) to 14.5\% (2014). The purpose of this study is to describe hand washing behavior of toddlers' caregiver on diarrhea and non diarrhea toddlers in village of Kintamani 2015, Kintamani, Bangli. The method used in conducting the study is cross-sectional study design. The study population was all parents who have toddlers in the village of Kintamani. Sample selection is done using multi-stage sampling method, where the sample is 54 children of parents who live in the village of Kintamani. The analysis was done descriptively. The results of the study showed good habbit for hand cleaning has the lowest incidence of having diarrhea $(14,89 \%)$ followed by less good habbit $(53,8 \%)$ and bad habbit of hand cleaning has the highest incidence for having diarrhea $(64,3)$.

Keywords: General Characteristics respondend, Hand Washing, diarrhea, Toddler 


\section{PENDAHULUAN}

Diare atau gastroenteritis merupakan salah satu penyakit menular yang angka kesakitan dan kematiannya tergolong tinggi. Menurut data WHO tahun 2013, diperkirakan ada 1,7 miliar kasus diare yang terjadi setiap tahunnya. ${ }^{1}$ Di Indonesia penyakit diare masih merupakan masalah kesehatan masyarakat, karena angka morbiditas dan mortalitasnya yang tinggiPada tahun 2000 Incidence Rate (IR) penyakit Diare 301/ 1000 penduduk, tahun 2003 naik menjadi $374 / 1000$ penduduk, tahun 2006 naik menjadi 423 /1000 penduduk dan tahun 2010 menjadi 411/1000 penduduk. $^{2}$

Berdasarkan data Puskesmas Kintamani kejadian diare masuk dalam 10 besar penyakit dengan angka terbanyak 928 dalam kurun waktu 2014. Kunjungan Puskesmas Kintamani I pada tahun 2014 dilaporkan mengalami peningkatan sebesar 216 kasus dibandingkan dengan kunjungan tahun 2013. Dari 8 Desa yang terdapat di wilayah kerja Kintamani I, terdapat salah satu desa yang kejadian diarenya dalam kurun waktu 2013 hingga 2014 mengalami peningkatan dan melebihi estimasi kejadian tahun yaitu Desa Kintamani. Angka kejadian bulan Januari hingga Desember tahun 2014 pada desa Kintamani mencapai 226 kasus.

Tingginya angka diare berdasarkan konsep Blum disebabkan oleh 4 faktor besar yaitu perilaku masyarakat, lingkungan, pelayanan kesehatan, dan genetik. Dalam permasalaan diare ini, faktor yang merupakan determinan adalah faktor perilaku dan faktor lingkungan yang saling tumpang tindih. Faktor perilaku yang dimaksud disini adalah perilaku hidup bersih dan sehat yang dilakukan atas kesadaran dari setiap anggota keluarga agar dapat menolong dirinya sendiri di bidang kesehatan. ${ }^{3}$ Salah satu indikator mengambil peran besar dalam kasus diare adalah perilaku mencuci tangan. ${ }^{3,4}$

Tingginya angka kejadian diare di Desa Kintamani dan keterkaitan program PHBS dengan pencegahan diare seharusnya dapat menjelaskan adanya kesenjangan diantara angka kejadian dengan keberhasilan program PHBS, salah satunya adalah tentang mencuci tangan dengan menggunakan air dan sabun. Pada suatu studi yang telah dilakukan juga didapatkan hubungan yang signifikan antara perilaku mencuci tangan dengan kejadian diare pada Balita. Dari permasalahan tersebut, penelitian ini akan meneliti gambaran perilaku mencuci tangan dan kaitannya dengan kejadian diare di Desa Kintamani. ${ }^{5,6}$

\section{METODE PENELITIAN}

Penelitian ini dilakukan di Desa Kintamani, wilayah kerja Puskesmas Kintamani Kecamatan Kintamani Kabupaten Bangli Provinsi Bali pada tahun 2015. Rancangan penelitian yang digunakan adalah deskriptif observasional dengan pendekatan desain cross sectional yaitu rancangan studi epidemiologi dimana pengukuran atau observasi terhadap variabel independen (faktor resiko) dan variabel dependen (efek) dilaksanakan pada satu waktu secara bersamaan. Penelitian ini melihat gambaran kejadian diare sebagai variabel dependen terhadap faktor resiko sumber air minum, perilaku mengolah air dan perilaku mencuci tangan sebagai variabel independen.

Sampel dalam penelitian adalah warga di Desa Kintamani Kecamatan Kintamani Kabupaten Bangli-Bali dengan kriteria inklusi yaitu mereka yang berdomisili di Desa Kintamani Kecamatan Kintamani Kabupaten Bangli-Bali, tidak cacat fisik dan atau mental serta bersedia menjadi untuk dijadikan sampel penelitian.

Untuk memperoleh data yang diinginkan, sampel dipilih dengan menggunakan teknik Multistage Sampling yang dilakukan melalui beberapa tahap, yaitu dengan penentuan beberapa banjar yang berada di desa kintamani dan beberapa kemudian penentuan kepala keluarga yang nantinya akan dijadikan sampel.

\section{HASIL PENELITIAN}

Pada penelitian ini, didapatkan 54 responden yang dilakukan survei dan observasi pada 5 banjar di desa Kintamani. Karakteristik umum subyek penelitian dapat dilihat di tabel 5.1.

Penelitian ini mendapatkan 54 sampel dari 54 sampel yang ditentukan. Dari 54 sampel tersebut didapatkan profil berupa pendidikan terakhir, umur responden, dan cara mencuci tangan. 


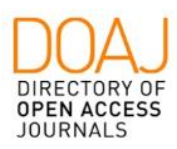

Data mengenai perilaku mencuci tangan didapat melalui kuisioner Likert dan observasi di rumah responden. Indikator yang dinilai ada 4, yaitu

Tabel 1. Kareteristik Umum Responden

\begin{tabular}{lll}
\hline $\begin{array}{l}\text { Pendidikan } \\
\text { Terakhir }\end{array}$ & Frekuensi & Persentase \\
\hline Tidak Sekolah & 9 & $16,7 \%$ \\
SD & 8 & $14,8 \%$ \\
SMP & 14 & $25,9 \%$ \\
SMA & 20 & $37 \%$ \\
Sarjana & 3 & $5,6 \%$ \\
& & \\
\hline Usia & & \\
\hline $20-25$ tahun & 11 & $20,4 \%$ \\
$26-30$ tahun & 14 & $25,9 \%$ \\
$31-35$ tahun & 11 & $20,4 \%$ \\
$36-40$ tahun & 6 & $11,1 \%$ \\
$>40$ tahun & 12 & $22,2 \%$ \\
\hline
\end{tabular}

Apabila semua maksimal 2 indikator tidak terpenuhi maka dikategorikan baik, apabila ada 3 yang tidak terpenuhi maka dikategorikan kurang baik. Kategori buruk didapatkan apabila responden tidak memenuhi minimal 4 indikator. Karaktersitik mengenai perilaku mencuci tangan dapat dilihat pada tabel 2.

Tabel 2. Perilaku Mencuci Tangan

\begin{tabular}{lll}
\hline Perilaku Mencuci & Frekuensi & Persentase \\
Tangan & & \\
\hline Baik & 27 & $50 \%$ \\
Kurang Baik & 13 & $24,1 \%$ \\
Buruk & 14 & $25,9 \%$ \\
\hline Total & 54 & $100 \%$ \\
\hline
\end{tabular}

Sampel pada penelitian ini mayoritas memiliki perilaku mencuci tangan yang baik, yaitu sebesar $50 \%$, diikuti oleh kebiasaan mencuci tangan yang buruk sebanyak $25,9 \%$ dan perilaku mencuci tangan yang kukup baik memiliki nilai sebesar $24,1 \%$.

Pada tabel 3 dapat dilihat tabulasi silang antara perilaku mencuci tangan dengan kejadian diare. Disini juga dapat dilihat bahwa pada perilaku mencuci tangan yang baik cenderung tidak mengalami diare $(85,2 \%)$, dibandingkan dengan perilaku cuci tangan kurang baik $(46,2 \%)$ dan perilaku cuci tangan yang buruk $(35,7 \%)$

Tabel 3. Perilaku Mencuci Tangan Berdasarkan Kejadian Diare

\begin{tabular}{llll}
\hline Perilaku Mencuci Tangan & \multicolumn{2}{l}{ Diare } & Total \\
\cline { 2 - 3 } & Ya & Tidak & \\
\hline Baik & $4(14,8 \%)$ & $23(85,2 \%)$ & 27 \\
Kurang Baik & $7(53,8 \%)$ & $6(46,2 \%)$ & 13 \\
Buruk & $9(64,3 \%)$ & $5(35,7 \%)$ & 14 \\
\hline Total & 20 & 34 & 54 \\
\hline
\end{tabular}

\section{PEMBAHASAN}

Kejadian diare cenderung terjadi pada perilaku mencuci tangan yang buruk $(64,3 \%)$ dibandingkan dengan perilaku cuci tangan yang baik $(14,8 \%)$ dan perilaku cuci tangan yang kurang baik $(53,8 \%)$. dan paling banyak mengalami kejadian diare adalah perilaku mencuci tangan yang buruk (64,3\%). Hasil ini didukung oleh penelitian yang dilakukan oleh Wohangara dkk tahun 2012 yang melaporkan bahwa persentase balita yang diare lebih banyak pada ibu yang tidak menerapkan perilaku mencuci tangan yang baik dan benar $(78,1 \%)$.

\section{SIMPULAN}

Umur responden yang terbanyak adalah 26-30 tahun yaitu sebanyak $25,9 \%$ dan yang tersedikit adalah kelompok umur 36-40 tahun yaitu sebanyak 11,1 \%. Umur responden termuda adalah 20 tahun sedangkan yang tertua adalah 65 tahun. Mayoritas pendidikan terakhir responden adalah SMA dengan nilai 37\%, sedangkan yang minoritas adalah Sarjana dengan nilai $5,6 \%$. Mayoritas responden yang berperilaku mencuci tangan dengan baik memiliki persentase $50 \%$. Perilaku 
mencuci tangan yang baik memiliki kejadian diare paling sedikit $(14,89 \%)$, diikuti oleh perilaku mencuci tangan kurang baik $(53,8 \%)$, dan paling banyak mengalami kejadian diare adalah perilaku mencuci tangan yang buruk (64,3\%).

Mengingat adanya tren kejadian diare yang meningkat apabila keluarga perilaku mencuci tangan yang buruk, maka perlu dilakukan penyuluhan kepada masyarakat desa Kintamani mengenai pentingnya mengolah air dengan baik dan mencuci tangan dengan baik dan benar.

\section{DAFTAR PUSTAKA}

1. Departemen Kesehatan R I. 2009, Buku Pedoman Pengendalian Penyakit Diare, Departemen Kesehatan RI, Jakarta.

2. Hung, B.V. 2006. The Most Common Causes and Risk Factors for Diarrhea Among children less than five years of age admitted to Dong Anh Hospital Hanoi, Northern Vietnam. Diakses pada tanggal 20 Februari 2015

3. Kusumawati, dkk. 2011. Hubungan Pemberian ASI Eksklusif dengan Angka Kejadian Diare Akut pada Bayi Usia 0-1 Tahun di Puskesmas Kuranji Kota Padang. Diakses tanggal 20 Februari 2015

4. Laporan Riskesdas 2007 Provinsi Bali. Badan Penelitian dan Pengembangan Kesehatan. Departemen Kesehatan RI

5. Supiyan, Zulfitri, Wolferst. 2013. Hubungan Penerapan Peilaku Hidup Bersih dan Sehat (PHBS) Tatanan Rumah Tangga Dengan Kejadian Diare pada Balita. Diakses pada tanggal 19 Februari 2015

6. World Health Organization 2013. Diarrhoeal Disease. Diakses tanggal 19 Februari 2015

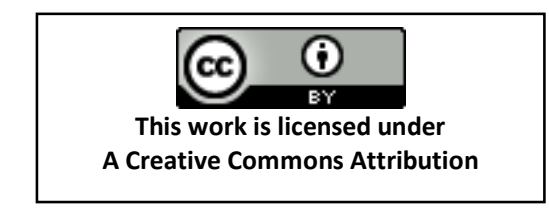

